\title{
DESKRIPSI KETERAMPILAN PROSES SAINS MAHASISWA CALON GURU FISIKA
}

\author{
Hamdani \\ Program Studi Pendidikan Fisika FKIP Universitas Tanjungpura \\ Jl. Prof. Dr. Hadari Nawawi Pontianak Kalimantan Barat \\ E-mail: hamdani052185@gmail.com
}

\begin{abstract}
This research was conducted to reveal the science process skills of pre-service physics teacher. There were 241 students (64 men and 177 women) were given the science process skills test. Overall average science process skills score of students at 48.88 with a low category. There are seven aspects of the science process skills were revealed. The average score of predicting 41.55; classifying 41.76; interpreting data 49.37; hypothesize 49.48; plan experiments 50.26; observing 50.34 and apply concepts 59.43. Science process skills of male did not differ significantly with female (sig. 0.717> 0.05). The physic education courses need to improve science process skills of students.
\end{abstract}

Keywords: science process skills, gender

Salah satu kompetensi mata pelajaran fisika berdasarkan Peraturan Menteri Pendidikan dan Kebudayaan nomor 64 Tahun 2013 antara lain merumuskan permasalahan yang berkaitan dengan fenomena fisika benda, merumuskan hipotesis, mendesain dan melaksanakan eksperimen, melakukan pengukuran secara teliti, mencatat dan menyajikan hasil dalam bentuk tabel dan grafik, menyimpulkan, serta melaporkan hasilnya secara lisan maupun tertulis. Kompetensi ini merupakan keterampilan proses sains. Menurut Karamustafaoglu (2011) keterampilan proses sains dapat dikelompokkan menjadi dua yaitu keterampilan proses sains dasar (basic science process skills) dan keterampilan proses sains terpadu (integrated science process skills).

\begin{abstract}
Keterampilan proses sains dasar tersebut meliputi mengamati yaitu menggunakan indera untuk mengumpulkan informasi tentang objek atau peristiwa; menyimpulkan yaitu membuat tebakan ilmiah (educated guess) tentang objek atau peristiwa berdasarkan data atau informasi yang dikumpulkan; mengukur yaitu menggunakan ukuran yang standar dan tidak standar untuk menentukan besar dari suatu objek; mengkomunikasikan: menggunakan kata-kata, tabel, atau grafik untuk menjelaskan objek atau peristiwa; mengelompokkan yaitu menentukan golongan objek atau fenomena berdasarkan kriteria dan sifatnya; meramalkan yaitu membuat dugaan atau meramalkan kemungkinan pada objek atau fenomena yang akan
\end{abstract}


terjadi berdasarkan bukti yang ada (Padila, 1990).

Keterampilan proses sains terintegerasi tersebut meliputi menentukan variabel yaitu mampu mengidentifikasi variabel bebas, variabel kontrol dan variabel terikat; menentukan langkah kerja yaitu kemampuan untuk mengukur variabel-variabel dalam percobaan; merumuskan hipotesis yaitu kemampuan menentukan hasil percobaan; interpretasi data yaitu kemampuan mengorganisasi data dan menarik kesimpulan berdasarkan data tersebut; eksperimen yaitu kemampuan melakukan percobaan, membuat hipotesis, mengidentifikasi dan mengontrol variabel, merancang dan melakukan percobaan dan menafsirkan hasil percobaan (Padila, 1990).

Pembelajaran sains di sekolah menekankan pada pemberian pengalaman belajar secara langsung melalui penggunaan dan pengembangan keterampilan proses dan sikap ilmiah (Rahayu, Susanto, Yulianti, 2011). Keterampilan proses sains (KPS) dan sikap ilmiah merupakan bagian dari sains itu sendiri, sehingga sangat strategis untuk dikembangkan. Walaupun menduduki posisi strategis dalam setiap kurikulum yang pernah diberlakukan di negeri ini, implementasi KPS di lapangan tidak sesuai dengan harapan. Guru sangat jarang menggunakan pendekatan KPS dalam pembelajaran IPA, walaupun karakteristik materi yang diajarkan sangat cocok menggunakan KPS (Suja, 2006).

Metode ilmiah, berpikir ilmiah dan berpikir kritis merupakan terminologi yang digunakan untuk menggambarkan atau menjelaskan keterampilan sains (Padila, 1990).
Keterampilan proses sains ini sesuai dengan pendekatan ilmiah (scientific) yang diterapkan pada kurikulum 2013. Pendekatan ilmiah tersebut terdiri mengamati, menanya, menalar, mencoba dan membentuk jejaring.

Mahasiswa pendidikan fisika merupakan calon guru fisika yang harus memiliki kompetensi (keterampilan proses sains) yang tertuang dalam Peraturan Menteri Pendidikan dan Kebudayaan Nomor 64 Tahun 2013. Keterampilan proses sains perlu dikuasai siswa untuk penyelidikan ilmiah dan proses pembelajaran yang dialami siswa (Harlen; Taconis, Ferguson-Hessler \& Broekkamp dalam Karsli, Sahin dan Ayas, 2009). Oleh karena itu keterampilan proses sains penting untuk diajarkan kepada mahasiswa sebagai calon guru yang mengajar siswa di sekolah kelak. Keterampilan proses sains tersebut dapat diperoleh melalaui perkuliahan baik teori maupun praktikum. Sebelum merancang perkuliahan (teori atau praktikum) untuk mengembangkan keterampilan proses sains pada mahasiswa, perlu dilakukan penelitian untuk mengungkap profil penguasaan keterampilan proses sains mahasiswa. Secara umum tujuan penelitian ini untuk mengungkap profil penguasaan keterampilan proses sains mahasiswa dan menyelidiki ada atau tidak perbedaan keterampilan proses sains antara mahasiswa laki-laki dan mahasiswa perempuan.

\section{METODE PENELITIAN}

Fokus penelitian ini mengungkap profil keterampilan proses sains mahasiswa calon guru fisika. Oleh karena itu metode penelitian yang akan digunakan berupa metode deskriptif dan penelitian survey merupakan bentuk 
penelitian yang diterapkan. Metode deskriptif adalah prosedur pemecahan masalah yang diselidiki dengan menggambarkan keadaan subyek atau obyek penelitian berdasarkan faktafakta yang tampak atau apa adanya (Nawawi, 2005). Penelitian survey bertujuan untuk memperoleh faktafakta dari gejala-gejala yang ada dan mencari keterangan-keterangan secara faktual (Nazir, 1983).

Seluruh populasi dalam penelitian ini dijadikan sampel. Oleh arena itu sampel dalam penelitian ini adalah mahasiswa tahun pertama, mahasiswa tahun kedua, mahasiswa tahun ketiga, dan mahasiswa tahun keempat pendidikan fisika FKIP Universitas Tanjungpura tahun ajaran 2016-2017 yang diberikan tes keterampilan proses sains. Secara keseluruhan ada 241 mahasiswa (64 laki-laki dan 177 perempuan) yang terlibat dalam penelitian ini.

Alat pengumpul data yang digunakan berupa tes keterampilan proses sains berbentuk pilihan ganda pada materi listrik dinamis yang

menguji keterampilan interpretasi, merencanakan percobaan, membuat hipotesis, menerapkan konsep, mengamati, memprediksi dan mengklasifikasi. Indikator aspek KPS tersebut disesuaikan berdasarkan referensi yang ditulis Rustaman (2005). Ada tiga soal yang mewakili tujuh aspek keterampilan proses sains, sehingga secara keseluruhan ada 21 soal. Tes ini diadopsi dari penelitian Hamdani (2013) dengan nilai reliabilitas 0,83 .

\section{HASIL DAN PEMBAHASAN \\ Keterampilan proses sains mahasiswa tiap aspek keterampilan proses sains}

Penelitian ini melibatkan mahasiswa pendidikan fisika tahun pertama sampai tahun keempat. Ada 241 mahasiswa (64 laki-laki dan 177 perempuan) yang diminta untuk menjawab tes keterampilan proses sains. Ada tujuh aspek keterampilan proses sains yang diujikan pada mahasiswa. Tiga soal diujikan pada mahasiswa yang mewakili tiap aspek. Secara keseluruhan ada 21 soal yang diujikan. Rata-rata skor keterampilan proses sains mahasiswa tiap aspek disajikan pada Gambar 1 di bawah ini.

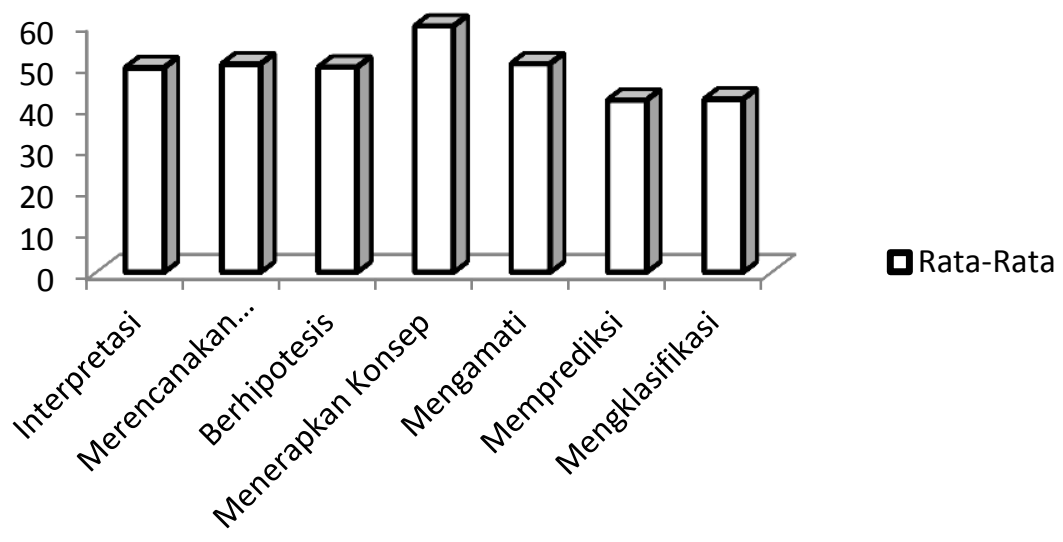

Gambar 1. Rata-rata skor keterampilan proses sains mahasiswa tiap aspek 
Secara keseluruhan rata-rata skor keterampilan proses tiap aspek tergolong rendah. Berdasarkan Gambar 1 rata-rata skor keterampilan proses sains tertinggi terjadi pada aspek menerapkan konsep sebesar 59,43 dan terendah pada aspek memprediksi sebesar 41,55.

Keterampilan proses sains mahasiswa berdasarkan cohort

Cohort dalam penelitian ini merupakan pengelompokkan mahasiswa berdasarkan jenjang tahun mahasiswa terdaftar sebagai mahasiswa. Mahasiswa semester satu merupakan mahasiswa tahun pertama, mahasiswa semester tiga digolongkan mahasiswa tahun kedua, mahasiswa semester lima dikelompokkan dalam mahasiswa tahun ketiga dan mahasiswa semester tujuh sebagai mahasiswa tahun keempat. Secara keseluruhan data mahasiswa berdasarkan cohort disajikan dalam Tabel 1.

Tabel 1. Jumlah mahasiswa tiap semester

Semester Jumlah Mahasiswa Mahasiswa Laki-laki Mahasiswa Perempuan

$\begin{array}{lccc}\text { I } & 65 & 14 & 51 \\ \text { III } & 57 & 18 & 39 \\ \text { V } & 70 & 18 & 52 \\ \text { VII } & 49 & 14 & 35\end{array}$

Skor rata-rata keterampilan proses sains tiap aspek berdasarkan jenjang (cohort) mahasiswa disajikan dalam Tabel 2.

Tabel 2. Skor rata-rata keterampilan proses sains tiap aspek berdasarkan jenjang (cohort) mahasiswa

\begin{tabular}{lrrrc}
\hline Aspek KPS & SEM I & SEM III & SEM V & SEM VII \\
\hline Interpretasi & 42,56 & 46,19 & 44,76 & 63,95 \\
Merencanakan Percobaan & 31,79 & 43,27 & 50,48 & 75,51 \\
Berhipotesis & 36,41 & 39,18 & 59,05 & 63,27 \\
Menerapkan Konsep & 39,49 & 43,28 & 68,57 & 86,39 \\
Mengamati & 18,46 & 38,01 & 66,67 & 78,23 \\
Memprediksi & 30,26 & 41,52 & 44,76 & 49,66 \\
Mengklasifikasi & 42,57 & 29,83 & 44,29 & 50,34 \\
\hline Rata-rata & 34,51 & 40,18 & 54,08 & 66,76 \\
\hline
\end{tabular}

Secara umum, berdasarkan Tabel 2 semakin tinggi jenjang (semester) mahasiswa semakin tinggi skor rata-rata keterampilan proses sains mahasiswa.

\section{Keterampilan proses sains mahasiswa berdasarkan gender}

Gender dapat diartikan sebagai jenis kelamin. Skor keterampilan proses sains mahasiswa berdasarkan gender diolah secara kualitatif dan kuantitatif. Tabel 3 merupakan data rata-rata skor keterampilan proses sains mahasiswa berdasarkan gender. 
Tabel 3. Skor rata-rata tiap aspek keterampilan proses sains berdasarkan gender

\begin{tabular}{lcc}
\hline Aspek KPS & Laki-Laki & Perempuan \\
\hline Interpretasi & 53,65 & 48,76 \\
Merencanakan Percobaan & 46,88 & 55,38 \\
Berhipotesis & 51,56 & 51,61 \\
Menerapkan Konsep & 65,11 & 72,69 \\
Mengamati & 48,44 & 56,87 \\
Memprediksi & 50,52 & 50,09 \\
Mengklasifikasi & 43,29 & 33,33 \\
\hline Rata-Rata & 51,35 & 52,68 \\
\hline
\end{tabular}

Berdasarkan uji normalitas diperoleh data skor KPS mahasiswa laki-laki dan mahasiswa perempuan tidak berdistribusi normal (nilai sig $0,026<0,05$ untuk skor KPS mahasiswa laki-laki dan nilai sig
$0,001<0,05$ untuk skor KPS mahasiswa perempuan). Hasil lengkap uji normalitas menggunakan program SPSS disajikan pada Tabel 4.

Tabel 4. Hasil uji normalitas

\begin{tabular}{|c|c|c|c|c|c|c|}
\hline \multicolumn{7}{|c|}{ Tests of Normality } \\
\hline \multirow[b]{2}{*}{ Gender } & \multicolumn{3}{|c|}{ Kolmogorov-Smirnov $^{\mathrm{a}}$} & \multicolumn{3}{|c|}{ Shapiro-Wilk } \\
\hline & Statistic & $\mathrm{df}$ & Sig. & Statistic & $d f$ & Sig. \\
\hline Laki-laki & ,118 & 64 & ,026 & ,962 & 64 & ,046 \\
\hline Perempuan & ,093 & 176 & ,001 & ,987 & 176 & ,111 \\
\hline
\end{tabular}

Karena data tidak berdistribusi normal maka uji U Mann Whitney dilakukan untuk menguji perbedaan keterampilan proses sains antara mahasiswa laki-laki dengan mahasiswa perempuan. Hasil uji U Mann Whitney menunjukkan nilai sig. 0,717 >0,05, dengan demikian $\mathrm{H}_{\mathrm{o}}$ diterima atau tidak ada perbedaan penguasaan KPS antara mahasiswa laki-laki dengan mahasiswa perempuan.

Secara berurutan rata-rata skor keterampilan proses sains mahasiswa dari yang terendah sampai yang tertinggi yaitu memprediksi, mengklasifikasi, berhipotesis, interpretasi, merencanakan percobaan, mengamati dan menerapkan konsep. Hasil ini sesuai dengan penelitian yang dilakukan oleh Zeidan dan Jayosi (2015) yang menunjukkan keterampilan mengamati merupakan keterampilan yang lebih mudah dibandingkan dengan keterampilan yang lain. Kasus yang sama juga ditemukan oleh Chabalengula, Mumba dan Mbewe (2012) yang menunjukkan keterampilan mengamati merupakan salah satu keterampilan dengan skor tinggi pada mahasiswa calon guru. Keterampilan mengamati merupakan keterampilan dasar (basic science process skills) yang relatif lebih mudah dikuasai dibandingkan dengan keterampilan proses sains terpadu (integrated science process skills). 
Secara umum rata-rata skor keterampilan proses sains mahasiswa $(48,88)$ tergolong rendah. Hal yang sama juga terjadi pada beberapa kasus di dunia. Beberapa hasil penelitian menujukkan mahasiswa calon guru memiliki pemahaman yang lemah tentang keterampilan proses sains (Emerole; Mbewe, et al., dalam Chabalengula, Mumba dan Mbewe (2012). Penelitian yang dilakukan Akar; Aydogdu dan Buldur; LacinSimsek dalam Aydogdu, Erkol dan Erten (2014) menunjukkan keterampilan proses sains mahasiswa calon guru sekolah dasar berada dalam kategori rendah. Penguasaan keterampilan proses sains yang lemah mungkin disebabkan perkuliahan yang dilakukan tidak secara menyeluruh melatih semua aspek keterampilan proses sains. Contohnya praktikum yang dirancang, tidak mengakomodasi seluruh aspek keterampilan proses sains. Penuntun praktikum yang ada tidak meminta mahasiswa membuat prediksi, mengidentifikasi variabel dan membuat hipotesis.

Semakin tinggi jenjang mahasiswa semakin baik penguasaan keterampilan proses sains. Hal ini mungkin disebabkan karena mahasiswa semester atas (jenjang mahasiswa yang tinggi) memiliki pengalaman yang lebih banyak dibandingkan dengan mahasiswa semester awal. Pengalaman tersebut diperoleh dari kegiatan praktikum dan kuliah yang telah mereka jalani. Hal ini sesuai dengan penelitian Indarto (2016) yang menyatakan terdapat pengaruh positif dan signifikan antara pengalaman terhadap prestasi belajar siswa dengan perolehan $t_{\text {hitung }}$ sebesar 2,337 dengan $\mathrm{p}=0,001(\mathrm{p}<0,05)$.

Walaupun rata-rata skor keterampilan proses sains mahasiswa perempuan sedikit lebih tinggi dari pada rata-rata skor keterampilan proses sains mahasiswa laki-laki, tetapi berdasarkan uji U Mann Whitney tidak ada perbedaan skor keterampilan proses sains antara mahasiswa laki-laki dan mahasiswa perempuan. Hal ini menunjukkan secara keseluruhan gender tidak mempengaruhi skor keterampilan proses sains. Hasil serupa juga ditemukan oleh Chabalengula, Mumba dan Mbewe (2012) yang menunjukkan tidak ada perbedaan keterampilan proses sains antara mahasiswa laki-laki dengan mahasiswa perempuan. Gender tak mempengaruhi skor KPS mungkin disebabkan karena kesempatan yang sama pada mahasiswa melakukan kegiatan praktikum di laboratorium. Hasil penelitian Iroegbu; Babajide; Johnson dan Johnson dalam Olufunke dan Adebayo (2014) menunjukkan tidak ada pengaruh gender dalam kegiatan praktikum pada jenjang sekolah menengah. Ercan dalam Aydogdu, Erkol dan Erten (2014) menemukan bahwa keterampilan proses sains guru sekolah dasar antara guru laki-laki dan guru perempuan tidak berebeda signifikan. Hasil penelitian ini berbeda dengan Zeidan dan Jayosi (2015) yang menunjukkan pada keterampilan proses sains siswa perempuan lebih unggul dibandingkan laki-laki. Menurut Stout, Ito, Finkelstein dan Pollock (2013) siswa perempuan cenderung dianggap memiliki kemampuan yang kurang dalam belajar fisika daripada siswa laki-laki.

\section{SIMPULAN DAN SARAN}

Berdasarkan analisis data dan pembahasan yang telah dilakukan, maka diperoleh antara lain penguasaan keterampilan proses sains 
mahasiswa calon guru fisika tergolong rendah, dengan rata-rata skor 48,88. Ada tujuh aspek keterampilan proses sains yang diungkap. Rata-rata skor kemampuan memprediksi 41,55; kemampuan mengklasifikasi 41,76; kemampuan interpretasi 49,37; kemampuan berhipotesis 49,48; kemampuan merencanakan percobaan 50,26; kemampuan mengamati 50,34 dan kemampuan menerapkan konsep 59,43. Hasil uji U Mann Whitney menunjukkan tidak ada perbedaaan keterampilan proses sains antara mahasiswa laki-laki dan mahasiswa perempuan (sig. 0,717 >0,05).

Saran perbaikan yang dapat dilakukan untuk meningkatkan keterampilan proses sains mahasiswa calon guru fisika antara lain perlu dirancang pembelajaran yang dapat meningkatkan keterampilan proses sains. Kegiatan virtual lab dan real lab atau kombinasi keduanya dapat mengasah keterampilan proses sain mahasiswa. Sesuai dengan hasil penelitian Chini, et al (2012); Saepuzaman (2011); Zacharia dan Constantinou yang menemukan penerapan kombinasi real lab dan virtual lab dapat meningkatkan keterampilan proses sains peserta didik. Soal keterampilan proses sains dapat menggunakan soal yang memisahkan keterampilan proses sains dasar (basic science process skills) dan keterampilan proses terintegerasi (integrated science process skills).

\section{DAFTAR PUSTAKA}

Aydogdu, B., Erkol, M., dan Erten, N. (2014). The investigation of science process skills of elementary school teachers in terms of some variables:
Perspectives from Turkey. Asia-Pacific Forum on Science Learning and Teaching, Vol. 15, No.1, 28.

Chabalengula, V.M., Mumba, F., dan Mbewe, S. (2012). How PreService Techers' Understand and Perform Science Process Skills. Eurasia Journal of Mathematics, Science \& Technology, Vol. 8, No.3, 167176.

Chini, J.J. et al (2012). "Exploration of Factor that Affect the Comparative Effectiveness of Physical and Virtual Manipulatives in an Undergraduate Laboratory". Physical Review Special Topics-Physics Education Research, Vol.8, No.1,1-13.

Hamdani, (2013). Penerapan Model ECIRR (Elicit-

Confront_identify-Resolve-

Reinforce) Menggunakan

Kombinasi Real Laboratory dan Virtual Laboratory untuk Mereduksi Miskonsepsi dan Meningkatkan Keterampilan Proses Sains Mahasiswa Tentang Konsep-Konsep Rangkaian Listrik. Tesis. UPI Bandung: Tidak diterbitkan.

Indarto, F. (2016). Pengaruh Pengalaman Mengajar dan Latar Belakang Guru Terhadap Prestasi Belajar Siswa Kelas XI Teknik Sepeda Motor SMKN 8 Purworejo Tahu Ajaran 2014/2015. Jurnal Pendidikan Teknik Otomotif, Vol.7, No.1, 106-110. 
Karamustafaoglu, S. (2011). Improving the Science Process Skills Ability of Science Student Teachers Using I Diagrams. Eurasian Journal of Physics and Chemistry Education, Vol.3, No.1, 26-38

Karsli, F., Sahin, C., Ayas, A. (2009). Determining Science Teachers' Ideas About the Science Process Skills: A Case Study. World Conference Education Science 2009. Procedia Social and Behavioral Sciences 1. 890895

Nawawi, H. (2005). Metode Penelitian Bidang Sosial. Edisi Revisi. Yogyakarta: Gadjah Mada University Press

Nazir, M. (1983). Metode Penelitian. Jakarta: Ghalia Indonesia

Olufunke, B. T. dan Adebayo, F. (2014). Effect of Gender on Basic Science Practical Skills of Lower Primary School Pupils. Journal of Emerging Trends in Educational Research and Policy Studies (JETERAPS), Vol.5, No.6, 679-683

Padila, M. J. (1990). The Science Process Skills. Research Matters- to the Science Teacher No. 9004 March 1, 1990. Retrieved Juni 4, 2016, from https://www.narst.org/ publications/research/skill.cfm

Peraturan Menteri Pendidikan dan Kebudayaan nomor 64 Tahun 2013
Rahayu, E., Susanto, H., Yulianti, D. (2011). Pembelajaran Sains dengan Pendekatan Keterampilan Proses untuk Meningkatkan Hasil Belajar dan Kemampuan Berpikir Kreatif Siswa. Jurnal Pendidikan Fisika Indonesia, Vol. 7, 106-110.

Rustaman, N, dkk. (2005). Strategi Belajar Mengajar Biologi. Malang: UM Press

Saepuzaman, D. (2011). Penerapan Model Pembelajaran Inkuiri Dengan kombinasi Eksperimen Nyata-Virtual Pada Materi Rangkaian Listrik Arus Searah Untuk Meningkatkan Penguasaan Konsep dan Keterampilan Proses Sains Siswa SMA. Tesis pada SPs UPI Bandung: Tidak diterbitkan

Stout, J. G, Ito, T. A., Finkelstein, N. D., dan Pollock, S. J. (2013). How a Gender Gap in Belonging Contributes to the Gender Gap in Physics Participation. Retrieved Juni 8, 2016 from http://www. colorado.edu/physics/Educatio nIssues/papers/Pollock/Stout \%20et\%20al\%202012_PERC _final_resubmitted.pdf

Suja, I. W. (2006). Profil Kompetensi Keterampilan Proses Sains Siswa Sekolah Dasar Di Kecamatan Buleleng. Jurnal Pendidikan dan Pengajaran IKIP Negeri Singaraja. Vol.39, No. 4, 769-781.

Zacharia, Z.C dan Constantinou, C. P. (2008). Comparing the Influence of Physical and 
Virtual Manipulatives in the Context of The Physics by Inquiry Curriculum: The Case of Undergraduate students' Conceptual Understanding of Heat and Temperature. American Journal of Physic, Vol.76, No.4\&5, 425-430.
Zeidan, A. H dan Jayosi, M.R., (2015). Science Process Skills and Attitudes toward Science among Palestinian Secondary School Students. World Journal of Education, Vol.5, No.1, 13-24. 